\title{
Three-Year Longitudinal Study: Prevalence of Salmonella Enterica in Chicken Meat is Higher in Supermarkets than Wet Markets from Mexico
}

\author{
Iván D. Regalado-Pineda ${ }^{1}$, Rene Rodarte-Medina ${ }^{1}$, Carolina N. Resendiz-Nava ${ }^{1} \mathbb{C}$, \\ Cinthia E. Saenz-Garcia ${ }^{1}$, Pilar Castañeda-Serrano ${ }^{2}$ and Gerardo M. Nava ${ }^{1, *(\mathbb{D})}$ \\ 1 Departamento de Investigación y Posgrado en Alimentos. Universidad Autónoma de Querétaro, Querétaro, \\ QRO 76010, Mexico; david_fc80@hotmail.com (I.D.R.-P.); rodarte.rene@hotmail.com (R.R.-M.); \\ carolina.resendiz.90@gmail.com (C.N.R.-N.); elizabeth.saenz.garcia@gmail.com (C.E.S.-G.) \\ 2 Centro de Enseñanza, Investigación y Extensión en Producción Avícola. Universidad Nacional Autónoma \\ de Mexico, Tláhuac, CDMX 13300, Mexico; pilarcs@unam.mx \\ * Correspondence: gerardomnava@gmail.com; Tel.: +52-442-467-6817
}

Received: 11 January 2020; Accepted: 26 February 2020; Published: 2 March 2020

check for updates

\begin{abstract}
Worldwide, chicken meat is considered one of the main sources of Salmonella enterica in humans. To protect consumers from this foodborne pathogen, international health authorities recommend the establishment of continuous Salmonella surveillance programs in meat. However, these programs are scarce in many world regions; thus, the goal of the present study was to perform a longitudinal surveillance of S. enterica in chicken meat in Mexico. A total of 1160 samples were collected and analyzed monthly from 2016 to 2018 in ten chicken meat retailers (supermarkets and wet markets) located in central Mexico. The isolation and identification of S. enterica was carried out using conventional and molecular methods. Overall, S. enterica was recovered from $18.1 \%(210 / 1160)$ of the chicken meat samples. Remarkably, during the three years of evaluation, S. enterica was more prevalent $(p<0.0001)$ in supermarkets $(27.2 \%, 158 / 580)$ than in wet markets $(9.0 \%, 52 / 580)$. The study was 3.8 times more likely (odds ratio $=3.8, p<0.0001$ ) to recover $S$. enterica from supermarkets than wet markets. Additionally, a higher prevalence $(p<0.05)$ of this pathogen was observed during the spring, summer, autumn, and winter in supermarkets compared with wet markets. Moreover, the recovery rate of $S$. enterica from supermarkets showed a gradual increase from $20.78 \%$ to $42 \%$ $(p<0.0001)$ from 2016 to 2018. Interestingly, no correlation $(p>0.05)$ was observed between the S. enterica recovery rate in chicken meat and reported cases of Salmonella infections in humans. Higher levels of $S$. enterica in chicken meat retailed in supermarkets are not unusual; this phenomenon has also been reported in some European and Asian countries. Together, these results uncover an important health threat that needs to be urgently addressed by poultry meat producers and retailers.
\end{abstract}

Keywords: Salmonella; chicken meat; supermarkets; wet markets; prevalence

\section{Introduction}

Infections caused by Salmonella remain an important threat for human health. It has been estimated that, worldwide, this pathogen causes $\sim 20$ million human cases and $\sim 140,000$ deaths per year [1]. In Mexico, the National Epidemiological Surveillance System reports more than 110,000 Salmonella infections in humans every year [2]. Importantly, raw chicken meat is considered to be one of the main sources of Salmonella for humans [3-5], and it was estimated that $\sim 30 \%$ of foodborne Salmonellosis worldwide could be linked to poultry meat [6].

In some countries, it is of particular interest to perform analysis of $S$. enterica in supermarkets and wet markets (places dedicated to sell fresh meat, fish, and produce, aka public markets) due to the 
significant differences in sanitary conditions between these two retail places [7-11]. Wet markets are an important source of affordable food; unfortunately, these places have been linked to major outbreaks of diseases due to poor hygiene conditions [12-15]. In fact, a higher prevalence of foodborne pathogens in wet markets compared to supermarkets has been documented in many countries [16-19]. Importantly, various studies have identified wet markets as an important source of S. enterica, where prevalence in chicken meat ranged between $20 \%$ and $75 \%$ [20-23]. In fact, some studies have reported higher levels of Salmonella contamination in poultry meat sold in wet markets compared to supermarkets $[18,20,24,25]$; however, a few studies have also reported opposite trends [26-29]. Unfortunately, these types of analyses are scarce in Mexico; thus, the aim of the present study was to analyze the prevalence of S. enterica in chicken meat retailers (wet markets and supermarkets) located in central Mexico.

\section{Materials and Methods}

\subsection{Sample Collection and Microbiological Analysis}

The analysis was carried out in chicken meat retailers, five wet markets, and five supermarkets, located in Central Mexico (Queretaro State, Lat Long = 20.588793, -100.389885). Every month for three years, from January 2016 to December 2018, a total of 1160 meat samples were collected from wet markets and supermarkets. These meat retailers distribute defeathered and eviscerated chicken carcasses obtained from commercial poultry processing plants. Samples were transported on ice to the laboratory for processing within $4 \mathrm{~h}$. The number of samples per type of market are described with detail in Supplementary Table S1. Briefly, in 2016, a total of 680 samples were collected and analyzed. In 2017 and 2018, 240 samples per year were collected and analyzed.

The isolation of S. enterica was performed as described elsewhere [12]. Briefly, each sample consisted of $25 \mathrm{~g}$ of skin, obtained from one leg and one thigh, homogenized in $225 \mathrm{~mL}$ of buffered peptone water (BPW) and incubated at $37{ }^{\circ} \mathrm{C}$ for $24 \mathrm{~h}$. For Salmonella enrichment, 0.1 and $1.0 \mathrm{~mL}$ aliquots of incubated-BPW were transferred to $10 \mathrm{~mL}$ of Rappaport-Vassiliadis and Tetrathionate plus iodine solution broth and incubated at 42 and $37^{\circ} \mathrm{C}$ for $24 \mathrm{~h}$, respectively. A loopful of the culture was streaked onto xylose lysine deoxycholate agar (XLD) supplemented with sodium novobiocin

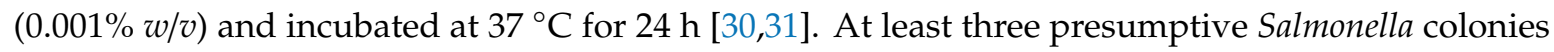
were streaked on Trypticase Soy agar to obtain pure cultures and then subjected to a urease test. The identification of Salmonella isolates was performed using PCR assays.

\subsection{Identification of S. enterica by PCR Assays}

The DNA samples from presumptive Salmonella isolates were subjected to PCR amplification using two Salmonella-specific assays targeting invA (primer forward: CTGTTGAACAACCCATTTGT and reverse: CGGATCTCATTAATCAACAAT) [32] and 16S rRNA genes (primer forward: ACGGTAACAGGAAGMAG and reverse: TATTAACCACAACACCT) [33]. PCR invA amplification ( $\sim 437 \mathrm{bp}$.) consisted of an initial denaturation step of $3 \mathrm{~min}$ at $94{ }^{\circ} \mathrm{C}$ and 35 cycles of $45 \mathrm{~s}$ at $94{ }^{\circ} \mathrm{C}, 30 \mathrm{~s}$ at $57.4^{\circ} \mathrm{C}$, and $30 \mathrm{~s}$ at $72{ }^{\circ} \mathrm{C}$, followed by a final extension of $5 \mathrm{~min}$ at $72{ }^{\circ} \mathrm{C}$. The protocol for $16 \mathrm{~S} r R N A$ amplification ( $402 \mathrm{bp}$.) was similar, except that 32 cycles of $20 \mathrm{~s}$ at $94{ }^{\circ} \mathrm{C}, 30 \mathrm{~s}$ at $53^{\circ} \mathrm{C}$, and $30 \mathrm{~s}$ at $72{ }^{\circ} \mathrm{C}$ were used. PCR products were analyzed on $1.5 \%$ agarose gels stained with ethidium bromide.

\subsection{Temperature, Precipitation, Chicken Meat Production, and Human Cases Correlation Analysis}

To uncover relationships between local weather conditions, amounts of chicken produced, and reported human Salmonellosis cases, official databases were consulted and data from 2016 to 2018 were retrieved, archived and analyzed. Monthly local temperatures were obtained from the National Meteorological Service (SMN, for its acronym in Spanish) [34]. Monthly chicken meat production was obtained from the National Service of Health, Food Safety (SENASICA, for its acronym in Spanish) [35], and monthly Salmonella human cases from the Weekly Epidemiological Bulletin-Secretary of Health (SSA, for its acronym in Spanish) [2]. 


\subsection{Statistical Analysis}

The results of $S$. enterica prevalence between years, seasons, and retailers were compared by the Chi-square test $[19,36]$ using XLSTAT software. Confidence intervals $(95 \%)$ for proportions were calculated using the Wilson procedure with a correction for continuity as described elsewhere [37]. Odds ratios (OR) and 95\% confidence intervals were calculated using MedCalc Software. The Pearson correlation coefficient and ANOVA (Tukey post hoc test) using temperature, precipitation, chicken meat production and human Salmonellosis cases data were also performed with the XLSTAT software. Differences were considered significant at $p<0.05$. Combined odds ratios (Synergy Factor) were estimated as described elsewhere [38].

To corroborate that sample number differences between years do not generate different outcomes, additional analyses were performed using a comparable number of samples $(n=240)$ per year. Briefly, a subset of samples ( $n=20$ per month) was selected from the whole 2016 sample collection using a random number generator (XLSTAT software). Statistical analyses were performed as described above.

\section{Results and Discussion}

Overall, S. enterica was recovered from $18.1 \%$ of the 1160 raw chicken meat samples analyzed. The prevalence of this pathogen increased $(p<0.001)$ over the three-year period evaluated, from $13.7 \%$ in 2016 to $27.1 \%$ in 2018 (Table 1). Comparable levels of S. enterica contamination (21.3\%) in chicken meat retailers have been observed in cross-sectional studies performed in the North, Central, and South regions of Mexico [39,40]. Additionally, this S. enterica prevalence in chicken meat has been observed in other world regions such as Australia, Belgium, Brazil, Canada, China, Colombia, Ecuador, Portugal, Spain, USA, Venezuela, and Wales, where contamination levels ranged between $9.5 \%$ and $65.0 \%,[19,26,27,41-44]$. These results indicate that chicken meat retailed in markets could represent an important risk factor for Salmonella infections in humans.

Table 1. Salmonella prevalence over time.

\begin{tabular}{cccc}
\hline & No. of Samples & Prevalence (\%) & $\mathbf{9 5 \%}$ CI \\
\hline Overall & & & \\
2016-2018 & 1160 & 18.1 & $15.9-20.5$ \\
Annual & & & \\
2016 & 680 & 13.7 & $11.2-16.6$ \\
2017 & 240 & 21.7 & $16.7-27.5$ \\
2018 & 240 & 27.1 & $21.7-33.3$ \\
Seasonal & & & \\
Spring & 312 & 15.1 & $11.4-19.6$ \\
Summer & 312 & 17.9 & $14.0-22.8$ \\
Autumn & 268 & 19.0 & $14.6-24.4$ \\
Winter & 268 & 20.9 & $16.3-26.4$ \\
Monthly & & & \\
January & 104 & 20.2 & $13.2-29.4$ \\
February & 104 & 19.2 & $12.4-28.4$ \\
March & 104 & 8.7 & $4.3-16.2$ \\
April & 104 & 22.1 & $14.8-31.5$ \\
May & 104 & 14.4 & $8.6-23.0$ \\
June & 104 & 17.3 & $10.9-26.3$ \\
July & 104 & 21.2 & $14.0-30.5$ \\
August & 104 & 15.4 & $9.3-24.1$ \\
September & 104 & 12.5 & $7.1-20.8$ \\
October & 104 & 19.2 & $12.4-28.4$ \\
November & 60 & 30.0 & $19.2-43.4$ \\
December & 60 & 25.0 & $15.1-38.1$ \\
\hline
\end{tabular}


The longitudinal design allowed us to perform a robust statistical assessment [45] of Salmonella contamination levels over different seasons. A few studies, from different world regions, have examined the presence of this pathogen in chicken meat retailers over one year period or longer, and some of them have reported discordant results regarding seasonal trends $[8,23,27,29,44]$; therefore, it is fundamental to perform multi-year analyses to corroborate temporal patterns of $S$. enterica contamination in chicken meat. After three years of microbiological examination, Salmonella isolation rates ranged from $8.7 \%$ to $30.0 \%$ per month and $15.1 \%$ to $20.9 \%$ per season. Nevertheless, statistical assessment revealed no significant ( $p>0.05$; odds ratio $>1.5,95 \%$ CI: 1.0-2.3) differences in the prevalence of S. enterica between months or seasons (Table 1). Interestingly, analysis of a single-year showed a higher $(p<0.01)$ isolation rate $(20.3 \%)$ in winter 2016 compared with the rest of the seasons; however, this tendency was not observed in 2017 (15.0\%) and 2018 (28.3\%) (Table 2), suggesting that seasonal trends may depend on other factors rather than seasonal conditions solely. To corroborate this idea, local seasonal conditions and poultry meat production were analyzed. No statistical relationships $(p>0.05)$ between temperature, precipitation, chicken meat production, and Salmonella prevalence in chicken meat were observed (data not shown). Moreover, another multi-year study revealed that seasonal differences in S. enterica prevalence are year-dependent [46]. Overall, these results support the lack of seasonal trends in S. enterica meat contamination and could help to explain the discordant seasonal trends reported in the literature $[8,28,29,36,44]$. Moreover, these results highlight the importance of performing a multi-year analysis for $S$. enterica seasonality assessment.

Table 2. Seasonal effect on Salmonella prevalence per year.

\begin{tabular}{cccc}
\hline Season & 2016 & 2017 & 2018 \\
\hline Spring & $24 / 192(12.5)^{\mathrm{b}}$ & $10 / 60(16.7)^{\mathrm{a}}$ & $13 / 60(21.7)^{\mathrm{a}}$ \\
Summer & $25 / 192(13.0)^{\mathrm{b}}$ & $15 / 60(25.0)^{\mathrm{a}}$ & $16 / 60(26.7)^{\mathrm{a}}$ \\
Autumn & $14 / 148(9.4)^{\mathrm{b}}$ & $18 / 60(30.0)^{\mathrm{a}}$ & $19 / 60(31.7)^{\mathrm{a}}$ \\
Winter $^{\mathrm{a}}$ & $30 / 148(20.3)^{\mathrm{a}}$ & $9 / 60(15.0)^{\mathrm{a}}$ & $17 / 60(28.3)^{\mathrm{a}}$ \\
\hline
\end{tabular}

Columns with different letter are statistically different (Chi-square test; $p<0.05)$.

Remarkably, the present multi-year study also revealed repeatable higher S. enterica contamination levels in chicken meat retailed at supermarkets than in wet markets. Overall, the recovery rate of S. enterica was higher $(p<0.0001)$ in supermarkets $(27.2 \%, 158 / 580)$ compared to wet markets $(9.0 \%, 52 / 580)$ (Figure 1A). The study showed that it was 3.8 times more likely (odds ratio $=3.8$, $p<0.0001)$ to recover S. enterica from supermarkets than wet markets (Table 3$)$. In the majority $(9 / 12)$ of the months analyzed, it was 3.7 to 29.4 times more likely $(p<0.019)$ to recover S. enterica from supermarkets than wet markets (Table 3). Additionally, in every year analyzed, from 2016 to 2018, the prevalence of this pathogen was higher $(p<0.001)$ in supermarkets $(20.8 \%, 30.8 \%$, and $41.7 \%$, respectively) than wet markets $(6.4 \%, 12.5 \%$, and $12.5 \%$, respectively) (Figure 1B); it was, at least, 3.1 times more likely $(p<0.019)$ to recover $S$. enterica from supermarkets than wet markets in the analyzed period (Table 3). Moreover, higher $(p<0.05)$ Salmonella contamination levels were observed in spring, summer, autumn, and winter in supermarkets (ranging from $23.1 \%$ to $36.6 \%$ ) compared with wet markets (ranging from $7.1 \%$ to $13.5 \%$ ) (Figure 1C); the analysis showed that it was between 1.9 and 10.5 times more likely $(p<0.05)$ to recover $S$. enterica from supermarkets than wet markets during each of the four seasons evaluated (Table 3). Interestingly, analysis of combined factors revealed a higher risk (combined odds ratio $=2.8,95 \%$ CI: 4.5-24.2, $p=0.028$ ) of Salmonella contamination when chicken meat was acquired in supermarkets during winter season compared to meat from wet markets (Table 4). Finally, to corroborate that results obtained in the present study were not influenced by differences in sample number per year (2016, 2017, and 2018), all statistical assessments were repeated using a similar number of samples $(n=240)$ per year. No significant differences between the two analyses were observed (Supplementary Tables and Figures). After three years of microbiological 
examination, it was observed that the prevalence of $S$. enterica in chicken meat retailed at supermarkets increased $(p<0.0001) 20.9 \%$ from 2016 to 2018. Importantly, our research group detected comparable contamination trends in markets from five other Mexican states, in which Salmonella recovery rates were higher $(p=0.009)$ in supermarkets $(9.9 \%, 17 / 171)$ and wet markets $(3.6 \%, 9 / 247)$ (unpublished results). Together, these results indicate that higher levels of Salmonella contamination in supermarkets were not a year-dependent phenomenon.

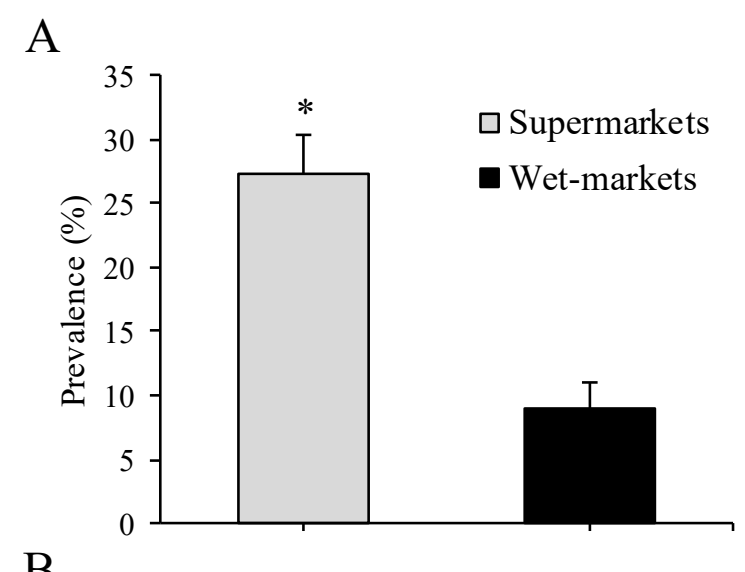

$\mathrm{B}$
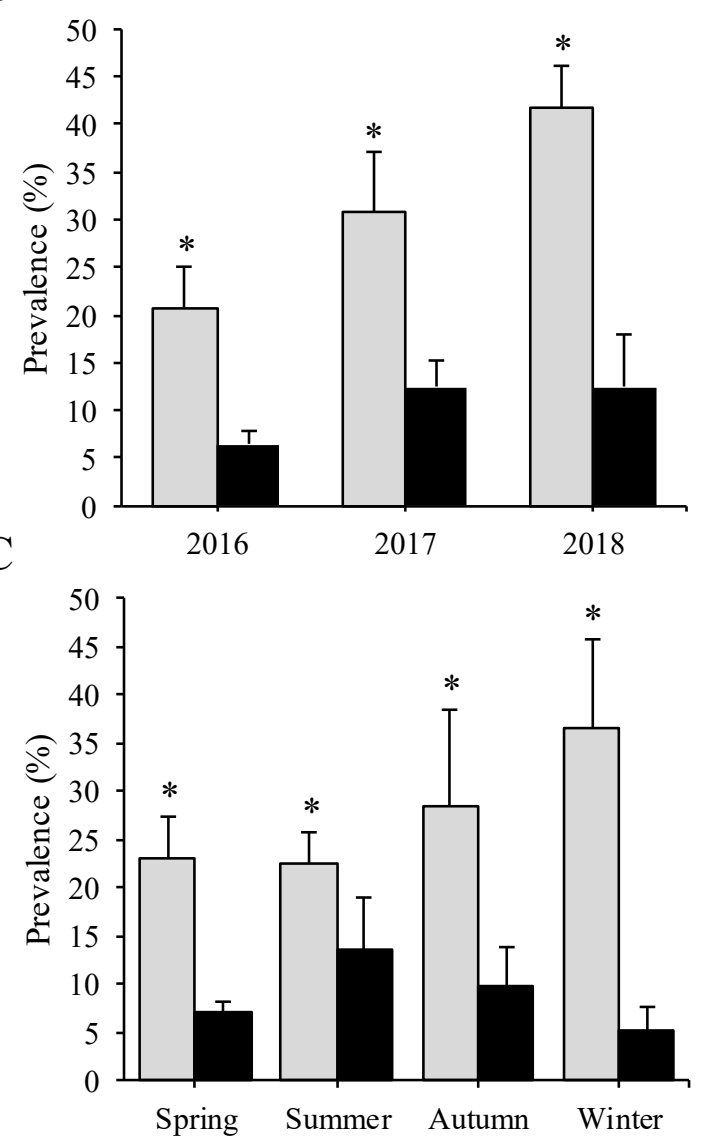

Figure 1. Salmonella prevalence in chicken meat influence by market type (A), year (B) and season $(\mathbf{C})$. Asterisks indicate statistical differences (Chi-square test; $p<0.05$ ) between supermarkets and wet-markets.

Higher rates of Salmonella contamination in chicken meat retailed in supermarkets is a surprising result because superior sanitary and quality standards are expected at these types of stores $[7,8]$. However, numerous reports from European and Asian countries have showed higher or comparable 
Salmonella contamination levels in meat samples from supermarkets when compared with wet markets samples $[8,23,26-29,44]$. For example, studies performed in Spain and Russia showed a higher $(p>0.05)$ Salmonella recovery rate $(75.0 \%$ and $60 \%$, respectively) in supermarkets than wet markets $(25.0 \%$ and $7.7 \%$, respectively) [26,47]. Additionally, studies from other world regions have reported no difference $(p>0.05)$ in Salmonella contamination levels in meat between these two types of retail markets [23,27-29]. The high frequency of Salmonella in chicken meat from supermarkets could be explained, in part, by the extended shelf life ( $\sim 6$ days) in these types of stores [48], compared with the few hours $(>16 \mathrm{~h})$ in which the product is traded in wet markets [26]. Nonetheless, further studies are required to identify the cause of this phenomenon. Taken together, these results uncover an important health threat that needs to be urgently addressed by poultry meat producers and retailers.

Table 3. Odds ratio analysis of the Salmonella prevalence in supermarkets over time.

\begin{tabular}{cccc}
\hline & Odds Ratio * & 95 \% Confidence Interval & $p$ Value \\
\hline Overall & & & \\
$2016-2018$ & 3.8 & $2.7-5.3$ & $p<0.0001$ \\
Months & & & \\
January & 4.2 & $1.4-12.5$ & $p=0.0104$ \\
February & 29.4 & $3.8-229.9$ & $p=0.0013$ \\
March & 3.9 & $0.8-19.7$ & $p=0.1008$ \\
April & 3.7 & $1.3-10.4$ & $p=0.0123$ \\
May & 4.9 & $1.3-18.6$ & $p=0.0194$ \\
June & 11.1 & $2.4-51.4$ & $p=0.0021$ \\
July & 1.6 & $0.6-4.1$ & $p=0.3390$ \\
August & 0.5 & $0.2-1.6$ & $p=0.2815$ \\
September & 0.8 & $0.3-2.7$ & $p=0.7670$ \\
October & 7.9 & $2.2-29.2$ & $p=0.0018$ \\
November & 9.0 & $2.2-36.2$ & $p=0.0020$ \\
December & 25.4 & $3.1-211.1$ & $p=0.0028$ \\
Season & & & \\
Spring & 4.0 & $1.9-8.1$ & $p=0.0002$ \\
Summer & 1.9 & $1.0-3.4$ & $p=0.0407$ \\
Autumn & 3.7 & $1.9-7.3$ & $p=0.0002$ \\
Winter & 10.5 & $4.5-24.2$ & $p<0.0001$ \\
Year & & & $p<0.0001$ \\
2016 & 3.8 & $2.3-6.3$ & $p=0.0008$ \\
2017 & 3.1 & $1.6-6.1$ & $p<0.0001$ \\
2018 & 5.0 & $2.6-9.6$ &
\end{tabular}

* Reference: Wet market (odds ratio $=1$ ).

Table 4. Combined odds ratio analysis of Salmonella prevalence.

\begin{tabular}{cccc}
\hline & Combined Odds Ratio $^{\mathbf{a}, *}$ & 95 \% Confidence Interval $^{*}$ & $p$ Value \\
\hline Supermarket*Spring & 1.0 & $0.47-2.29$ & $p=0.922$ \\
Supermarket*Summer & 0.5 & $0.25-0.97$ & $p=0.040$ \\
Supermarket*Autumn & 1.0 & $0.45-2.08$ & $p=0.940$ \\
Supermarket*Winter & 2.8 & $4.5-24.2$ & $p=0.028$ \\
Year & & & \\
Supermarket*2016 & 1.0 & $0.55-1.83$ & $p=0.990$ \\
Supermarket*2017 & 0.8 & $0.38-1.73$ & $p=0.604$ \\
Supermarket*2018 & 1.3 & $0.63-2.74$ & $p=0.464$ \\
\hline
\end{tabular}

${ }^{a}$ Combined odds ratio (Synergy factor) estimated as described by [38]. * Reference: Wet-market (odds ratio $=1$ ).

To gain insights into the contribution of chicken meat contaminated with Salmonella to human Salmonellosis in Mexico, we performed regression analysis using monthly prevalence results (present 
study), and the monthly number of human Salmonellosis cases reported from 2016 to 2018 by the Weekly Epidemiological Bulletin - SSA. According to this epidemiological report, the monthly prevalence rate of human Salmonellosis was higher $(p>0.05)$ in 2016 (average $=1.6$ cases per 100,000 people), followed by 2017 ( 1.1 cases per 100,000 people), and 2018 ( 0.6 cases per 100,000 people). Interestingly, no statistical relationships $\left(p>0.05, \mathrm{R}^{2}<0.13\right)$ were observed between overall Salmonella prevalence in chicken meat and human Salmonellosis cases reported between 2016 and 2018 (Figure 2A). Likewise, no relationships $\left(p>0.05, R^{2}<0.33\right)$ were observed between Salmonella prevalence in chicken meat retailed at supermarkets or wet markets and human Salmonellosis cases reported during the evaluated period (Figure 2B,C). Other reports have documented this lack of association between Salmonella contamination in chicken meat and human cases [41,46]; however, we believe that there is not enough evidence to rule out chicken meat as an important source of Salmonella for humans in Mexico [4]. Salmonella foodborne transmission is a complex biological trait and Salmonella meat prevalence data may not be enough to establish epidemiological links [4]. Thus, further and comprehensive studies, such as virulence or genomic profiling, are required to elucidate the contribution of chicken meat to the Salmonellosis cases in humans.

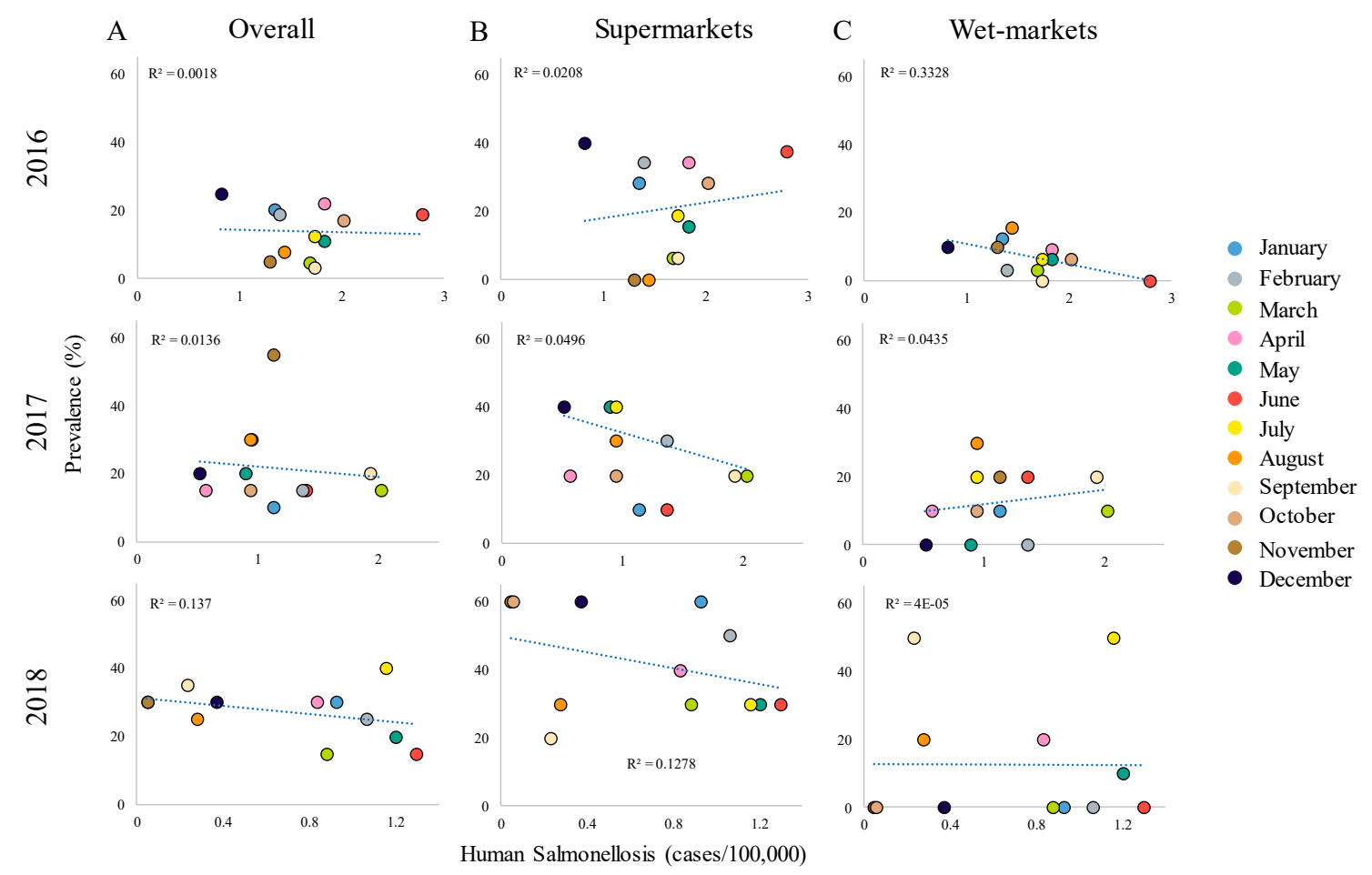

Figure 2. Correlation between Salmonella prevalence in chicken meat retailers and human salmonellosis cases. Analyses were performed using overall (A), supermarkets (B), wet-markets (C) Salmonella prevalence in chicken meat versus number of Salmonellosis cases.

\section{Conclusions}

The overall prevalence of S. enterica was $18 \%$ in chicken meat retailed in markets from central Mexico. Interestingly, Salmonella contamination levels were consistently higher in supermarkets than in wet markets. Additionally, it was revealed that the prevalence of this pathogen in chicken meat has increased in the last three years in this Mexican region. Together, these results uncover an important health threat that needs to be urgently addressed by poultry meat producers and retailers. We hope that these data serve as a framework for the poultry industry, policy makers, and health authorities to establish effective Salmonella control programs.

Supplementary Materials: The following are available online at http://www.mdpi.com/2304-8158/9/3/264/s1, Figure S1: Influence by market type (A), over time (B) and season effect (C) on Salmonella prevalence in chicken 
meat. Figure S2: Correlation between Salmonella prevalence in retail chicken meat and human salmonellosis cases. Table S1: Salmonella Prevalence over time. Table S2: Seasonal effect on Salmonella prevalence per year. Table S3: Odds ratio analysis of the Salmonella prevalence over time.

Author Contributions: I.D.R.-P., P.C.-S. and G.M.N. conceptualized the study, I.D.R.-P., R.R.-M., C.N.R.-N., C.E.S.-G., and G.M.N. preformed experiments and analyzed the data, I.D.R.-P., R.R.-M., C.N.R.-N., C.E.S.-G., P.C.-S., and G.M.N. interpreted results, wrote and revised the manuscript. All authors have read and agreed to the published version of the manuscript.

Funding: This research was funded by grant FOFIUAQ-2018 number FAC2018XX from the Universidad Autonoma de Queretaro.

Acknowledgments: We would like to thank all members of the Molecular Microbiology Laboratory, UAQ-FQ for their technical support.

Conflicts of Interest: The authors declare no conflict of interest.

\section{References}

1. Kirk, M.D.; Pires, S.M.; Black, R.E.; Caipo, M.; Crump, J.A.; Devleesschauwer, B.; Döpfer, D.; Fazil, A.; Fischer-Walker, C.L.; Hald, T;; et al. World Health Organization Estimates of the Global and Regional Disease Burden of 22 Foodborne Bacterial, Protozoal, and Viral Diseases, 2010: A Data Synthesis. PLoS Med. 2015, 12, e1001921.

2. NESS. National Epidemiological Surveillance System. 2017. Available online: https://www.gob.mx/ salud/acciones-y-programas/direccion-general-de-epidemiologia-boletin-epidemiologico (accessed on 26 August 2019).

3. Antunes, P.; Mourão, J.; Campos, J.; Peixe, L. Salmonellosis: The role of poultry meat. Clin. Microbiol. Infect. 2016, 22, 110-121. [CrossRef] [PubMed]

4. Cox, N.A.; Cason, J.A.; Richardson, L.J. Minimization of Salmonella contamination on raw poultry. Annu. Rev. Food Sci. Technol. 2011, 2, 75-95. [CrossRef] [PubMed]

5. Shah, D.H.; Paul, N.C.; Sischo, W.C.; Crespo, R.; Guard, J. Population dynamics and antimicrobial resistance of the most prevalent poultry-associated Salmonella serotypes. Poult. Sci. 2017, 96, 687-702. [CrossRef] [PubMed]

6. Hoffmann, S.; Devleesschauwer, B.; Aspinall, W.; Cooke, R.; Corrigan, T.; Havelaar, A.; Angulo, F.; Gibb, H.; Kirk, M.; Lake, R.; et al. Attribution of global foodborne disease to specific foods: Findings from a World Health Organization structured expert elicitation. PLoS ONE 2017, 12, e0183641. [CrossRef] [PubMed]

7. Villalpando-Guzmán, S.; Vázquez-Quiñones, C.R.; Natividad-Bonifacio, I.; Curiel-Quesada, E.; Quiñones-Ramírez, E.I.; Vázquez-Salinas, C. Frequency, antimicrobial susceptibility and adherence patterns of Salmonella enterica isolated from chicken meat, beef and pork from Mexico City. Rev. Chil. Infectol. 2017, 34, 458-466. [CrossRef]

8. Zhu, J.; Wang, Y.; Song, X.; Cui, S.; Xu, H.; Yang, B.; Huang, J.; Liu, G.; Chen, Q.; Zhou, G.; et al. Prevalence and quantification of Salmonella contamination in raw chicken carcasses at the retail in China. Food Control 2014, 44, 198-202. [CrossRef]

9. Mele, C.; Ng, M.; Chim, M.B. Urban markets as a 'corrective' to advanced urbanism: The social space of wet markets in contemporary Singapore. Urban Stud. 2014, 52, 103-120. [CrossRef]

10. Lazaro, J.; Kapute, F.; Holm, R.H. Food safety policies and practices in public spaces: The urban water, sanitation, and hygiene environment for fresh fish sold from individual vendors in Mzuzu, Malawi. Food Sci. Nutr. 2019, 7, 2986-2994. [CrossRef]

11. Lo, M.Y.; Ngan, W.Y.; Tsun, S.M.; Hsing, H.-L.; Lau, K.T.; Hung, H.P.; Chan, S.L.; Lai, Y.Y.; Yao, Y.; Pu, Y.; et al. A Field Study into Hong Kong's Wet Markets: Raised Questions into the Hygienic Maintenance of Meat Contact Surfaces and the Dissemination of Microorganisms Associated With Nosocomial Infections. Front. Microbiol. 2019, 10, 2618. [CrossRef]

12. Nidaullah, H.; Abirami, N.; Shamila-Syuhada, A.K.; Chuah, L.-O.; Nurul, H.; Tan, T.P.; Abidin, F.W.Z.; Rusul, G. Prevalence of Salmonella in poultry processing environments in wet markets in Penang and Perlis, Malaysia. Vet. World 2017, 10, 286-292. [CrossRef]

13. Wu, T.; Perrings, C.; Kinzig, A.; Collins, J.P.; Minteer, B.A.; Daszak, P. Economic growth, urbanization, globalization, and the risks of emerging infectious diseases in China: A review. Ambio 2017, 46, 18-29. [CrossRef] 
14. Chomel, B.B.; Belotto, A.; Meslin, F.-X. Wildlife, Exotic Pets, and Emerging Zoonoses. Emerg. Infect. Dis. 2007, 13, 6-11. [CrossRef]

15. Lynteris, C. The Prophetic Faculty of Epidemic Photography: Chinese Wet Markets and the Imagination of the Next Pandemic. Vis. Anthropol. 2016, 29, 118-132. [CrossRef]

16. Fang, J.; Shen, Y.; Qu, D.; Han, J. Antimicrobial resistance profiles and characteristics of integrons in Escherichia coli strains isolated from a large-scale centralized swine slaughterhouse and its downstream markets in Zhejiang, China. Food Control 2019, 95, 215-222. [CrossRef]

17. Odwar, J.A.; Kikuvi, G.; Kariuki, J.N.; Kariuki, S. A cross-sectional study on the microbiological quality and safety of raw chicken meats sold in Nairobi, Kenya. BMC Res. Notes 2014, 7, 627. [CrossRef]

18. Scheinberg, J.; Doores, S.; Cutter, C.N. A Microbiological Comparison of Poultry Products Obtained from Farmers' Markets and Supermarkets in Pennsylvania. J. Food Saf. 2013, 33, 259-264. [CrossRef]

19. Ghafir, Y.; China, B.; Korsak, N.; Dierick, K.; Collard, J.-M.; Godard, C.; De Zutter, L.; Daube, G. Belgian Surveillance Plans To Assess Changes in Salmonella Prevalence in Meat at Different Production Stages. J. Food Prot. 2005, 68, 2269-2277. [CrossRef]

20. Khan, A.S.; Georges, K.; Rahaman, S.; Abdela, W.; Adesiyun, A.A. Prevalence and serotypes of Salmonella spp. on chickens sold at retail outlets in Trinidad. PLoS ONE 2018, 13, e0202108.

21. Saiyudthong, S.; Trevanich, S. An Optimized EMA-RAPD-PCR for a Reliable Detection of Viable Salmonella spp. in Chicken Products. J. Food Saf. 2013, 33, 247-258.

22. Donado-Godoy, P.; Clavijo, V.; León, M.; Tafur, M.A.; Gonzales, S.; Hume, M.; Alali, W.; Walls, I.; Lo Fo Wong, D.M.A.; Doyle, M.P. Prevalence of Salmonella on Retail Broiler Chicken Meat Carcasses in Colombia. J. Food Prot. 2012, 75, 1134-1138. [CrossRef]

23. abu bakar, S.; Son, R.; Mahyudin, N.A.; Rukayadi, Y.; Tuan Chilek, T.Z. Prevalence of Salmonella spp. in chicken and beef from retail outlets in Malaysia. Int. Food Res. J. 2017, 24, 437-449.

24. Donado-Godoy, P.; Clavijo, V.; León, M.; Arevalo, A.; Castellanos, R.; Bernal, J.; Tafur, M.A.; Ovalle, M.V.; Alali, W.Q.; Hume, M.; et al. Counts, Serovars, and Antimicrobial Resistance Phenotypes of Salmonella on Raw Chicken Meat at Retail in Colombia. J. Food Prot. 2014, 77, 227-235. [CrossRef]

25. Ta, Y.T.; Nguyen, T.T.; To, P.B.; Pham, D.X.; Le, H.T.H.; Alali, W.Q.; Walls, I.; Lo Fo Wong, D.M.A.; Doyle, M.P. Prevalence of Salmonella on Chicken Carcasses from Retail Markets in Vietnam. J. Food Prot. 2012, 75, 1851-1854. [CrossRef]

26. Capita, R.; Alvarez-Astorga, M.; Alonso-Calleja, C.; Moreno, B.; del Camino García-Fernández, M. Occurrence of Salmonellae in retail chicken carcasses and their products in Spain. Int. J. Food Microbiol. 2003, 81, 169-173. [CrossRef]

27. Harrison, W.A.; Griffith, C.J.; Tennant, D.; Peters, A.C. Incidence of Campylobacter and Salmonella isolated from retail chicken and associated packaging in South Wales. Lett. Appl. Microbiol. 2001, 33, 450-454. [CrossRef]

28. Huang, J.; Zong, Q.; Zhao, F.; Zhu, J.; Jiao, X. Quantitative surveys of Salmonella and Campylobacter on retail raw chicken in Yangzhou, China. Food Control 2016, 59, 68-73. [CrossRef]

29. Minami, A.; Chaicumpa, W.; Chongsa-Nguan, M.; Samosornsuk, S.; Monden, S.; Takeshi, K.; Makino, S.; Kawamoto, K. Prevalence of foodborne pathogens in open markets and supermarkets in Thailand. Food Control 2010, 21, 221-226. [CrossRef]

30. Cason, J.A.; Cox, N.A.; Buhr, R.J.; Richardson, L.J. Comparison of the statistics of Salmonella testing of chilled broiler chicken carcasses by whole-carcass rinse and neck skin excision. Poult. Sci. 2010, 89, 2038-2040. [CrossRef]

31. Choi, D.; Chon, J.-W.; Kim, H.-S.; Kim, D.-H.; Lim, J.-S.; Yim, J.-H.; Seo, K.-H. Incidence, Antimicrobial Resistance, and Molecular Characteristics of Nontyphoidal Salmonella Including Extended-Spectrum $\beta$-Lactamase Producers in Retail Chicken Meat. J. Food Prot. 2015, 78, 1932-1937. [CrossRef]

32. Liu, T.; Liljebjelke, K.; Bartlett, E.; Hofacre, C.; Sanchez, S.; Maurer, J.J. Application of nested polymerase chain reaction to detection of Salmonella in poultry environment. J. Food Prot. 2002, 65, 1227-1232. [CrossRef] [PubMed]

33. Søborg, D.A.; Hendriksen, N.B.; Kilian, M.; Kroer, N. Widespread Occurrence of Bacterial Human Virulence Determinants in Soil and Freshwater Environments. Appl. Environ. Microbiol. 2013, 79, 5488-5497. [CrossRef] [PubMed] 
34. Resúmenes Mensuales de Temperaturas y Lluvia. Available online: https://smn.conagua.gob.mx/ es/climatologia/temperaturas-y-lluvias/resumenes-mensuales-de-temperaturas-y-lluvias (accessed on 7 January 2020).

35. Servicio de Información Agroalimentaria y Pesquera. Boletín Mensual de Avance de la Producción de Carne en Canal de Ave. Available online: http://www.gob.mx/siap/documentos/boletin-mensual-de-avances-de-laproduccion-de-carne-de-ave (accessed on 7 January 2020).

36. Ni, P.; Xu, Q.; Yin, Y.; Liu, D.; Zhang, J.; Wu, Q.; Tian, P.; Shi, X.; Wang, D. Prevalence and characterization of Salmonella serovars isolated from farm products in Shanghai. Food Control 2018, 85, 269-275. [CrossRef]

37. Wang, L.Y.R.; Jokinen, C.C.; Laing, C.R.; Johnson, R.P.; Ziebell, K.; Gannon, V.P.J. Multi-Year Persistence of Verotoxigenic Escherichia coli (VTEC) in a Closed Canadian Beef Herd: A Cohort Study. Front. Microbiol. 2018, 9, 2040. [CrossRef]

38. Cortina-Borja, M.; Smith, A.D.; Combarros, O.; Lehmann, D.J. The synergy factor: A statistic to measure interactions in complex diseases. BMC Res. Notes 2009, 2, 105. [CrossRef]

39. Miranda, J.M.; Mondragón, A.C.; Martinez, B.; Guarddon, M.; Rodriguez, J.A. Prevalence and antimicrobial resistance patterns of Salmonella from different raw foods in Mexico. J. Food Prot. 2009, 72, 966-971. [CrossRef]

40. Zaidi, M.B.; Calva, J.J.; Estrada-Garcia, M.T.; Leon, V.; Vazquez, G.; Figueroa, G.; Lopez, E.; Contreras, J.; Abbott, J.; Zhao, S.; et al. Integrated food chain surveillance system for Salmonella spp. in Mexico. Emerg. Infect. Dis. 2008, 14, 429-435. [CrossRef]

41. Fearnley, E.; Raupach, J.; Lagala, F.; Cameron, S. Salmonella in chicken meat, eggs and humans; Adelaide, South Australia, 2008. Int. J. Food Microbiol. 2011, 146, 219-227. [CrossRef]

42. Giombelli, A.; Gloria, M.B.A. Prevalence of Salmonella and Campylobacter on broiler chickens from farm to slaughter and efficiency of methods to remove visible fecal contamination. J. Food Prot. 2014, 77, 1851-1859. [CrossRef]

43. Vinueza-Burgos, C.; Cevallos, M.; Ron-Garrido, L.; Bertrand, S.; De Zutter, L. Prevalence and Diversity of Salmonella Serotypes in Ecuadorian Broilers at Slaughter Age. PLoS ONE 2016, 11, e0159567. [CrossRef]

44. Wang, Y.; Chen, Q.; Cui, S.; Xu, X.; Zhu, J.; Luo, H.; Wang, D.; Li, F. Enumeration and characterization of Salmonella isolates from retail chicken carcasses in Beijing, China. Foodborne Pathog. Dis. 2014, 11, 126-132. [CrossRef] [PubMed]

45. Caruana, E.J.; Roman, M.; Hernández-Sánchez, J.; Solli, P. Longitudinal studies. J. Thorac. Dis. 2015, 7, E537-E540. [PubMed]

46. Sivaramalingam, T.; McEwen, S.A.; Pearl, D.L.; Ojkic, D.; Guerin, M.T. A temporal study of Salmonella serovars from environmental samples from poultry breeder flocks in Ontario between 1998 and 2008. Can. J. Vet. Res. 2013, 77, 1-11. [PubMed]

47. Alali, W.Q.; Gaydashov, R.; Petrova, E.; Panin, A.; Tugarinov, O.; Kulikovskii, A.; Mamleeva, D.; Walls, I.; Doyle, M.P. Prevalence of Salmonella on retail chicken meat in Russian Federation. J. Food Prot. 2012, 75, 1469-1473. [CrossRef] [PubMed]

48. Kozačinski, L.; Cvrtila Fleck, Ž.; Kozačinski, Z.; Filipović, I.; Mitak, M.; Bratulić, M.; Mikuš, T. Evaluation of shelf life of pre-packed cut poultry meat. Vet. Arh. 2012, 82, 47-58.

(C) 2020 by the authors. Licensee MDPI, Basel, Switzerland. This article is an open access article distributed under the terms and conditions of the Creative Commons Attribution (CC BY) license (http://creativecommons.org/licenses/by/4.0/). 